\title{
A comparison of the measurement of gamma glob
in cerebrospinal fluid by electrophoretic and immunological methods
}

\author{
JACK COLOVER, ${ }^{1}$ J. G. FEINBERG, ANNE TEMPLE, AND \\ MARIAN TOOLEY \\ From the Institute of Clinical Research and Department of Neurology, Middlesex Hospital, London, \\ $W .1$, and the Bencard Allergy Research Unit, Beecham Research \\ Laboratories Limited, Betchworth, Surrey
}

SYNOPSIS The results of measurement of $\gamma$ globulin in the cerebrospinal fluid by electrophoresis and by an immunological technique are compared. In some fluids marked discrepancies were 5 found. Such discrepancies, when substantiated and better understood, may have diagnostic $\vec{c}_{\vec{c}}^{-}$ significance.

Since it is now possible to measure $\gamma$ globulin both by electrophoretic and immunological techniques, it was considered to be of interest to examine a number of spinal fluids in this way and to compare the results obtained. It was hoped that the findings might throw light on the very difficult problem of the origin of the $\gamma$ globulin in the cerebrospinal fluid and also to detect abnormal formation of this material in various neurological diseases.

Recent work indicates that some proteins which are present in the cerebrospinal fluid are not present in the serum. Thus Dencker and Swahn (1962) described three hitherto unknown fractions in the $\beta 2$ and $\gamma$ globulin zone of the cerebrospinal fluid, and called them $\mathrm{CB}_{2} \ldots 1, \mathrm{CB}_{2} . .2$, and $\mathrm{C} \gamma$ globulin. To identify these proteins they used an antiserum against pooled human cerebrospinal fluid. The work of Frick and Scheid-Seydel (1960), who used radioactive labelled proteins, suggested that in certain diseases proteins were present in the cerebrospinal fluid which were not coming from the serum. MacPherson and Cosgrove (1961) have also demonstrated in normal cerebrospinal fluid a 'minor $\gamma$ globulin' immunologically different from serum $\gamma$ globulin and a 'major' globulin, which is immunologically identical with serum $\gamma$ globulin. There is also some work suggesting that the serum haptoglobulins may not be normally found in the cerebrospinal fluid.

${ }^{1}$ Member of the external scientific staff, Medical Research Council. Received for publication 13 February 1963.
It seems possible that the $\gamma$ globulin in cerebrosspinal fluid might be derived from a number of different sources: from the serum $\gamma$ globulin; from cells inside the confines of the meninges; froma breakdown products of nervous tissue which $\frac{}{\circ}$ electrophoretically travel like $\gamma$ globulin.

It was considered that studies of the type reportedō in this paper might throw light on these problems, and we present here a preliminary report on a small number of patients.

\section{METHODS AND MATERIALS}

Seventeen cerebrospinal fluids obtained during the course of routine diagnostic lumbar puncture at the Middlesex? Hospital were studied. They were kept in a deep freeze? at $-30^{\circ} \mathrm{C}$. and the oldest fluid had been stored for eight months. The total protein was estimated at the Courtauld? Institute of Biochemistry using a standard sulphosalicylic acid precipitation method (King and Hazelwood, 1936) Electrophoresis of $0.5 \mathrm{ml}$. samples was done after pre- $N$ liminary concentration in cells made by Electrotherma N Engineering Ltd. (Colover, 1961a and b).

The strips were run and stained as described by Colover? using naphthalene black as the staining agent. This staine was shown to be highly sensitive to low protein con-D centrations such as are found in cerebrospinal fluid, and? to give a high order of accuracy for quantitative esti-0 mations. After oiling, the strips were scanned autoo matically by transmitted light in the Antares scanner $\overrightarrow{\mathbb{Q}}$ Copies of the scans obtained on squared paper were cut up and the proportionate amount of each componene estimated by weighing each area of the paper. The figures for a normal series of cerebrospinal fluids obtainech 
TABLE I

RELATIVE COMPOSITION OF NORMAL CEREBROSPINAL FLUID ${ }^{1}$

\begin{tabular}{|c|c|c|c|c|c|c|c|c|}
\hline & Pre-albumin & Albumin & $\begin{array}{l}\text { Pre-albumin } \\
\text { and Albumin } \\
\text { Combined }\end{array}$ & $a_{1}$ & $a_{2}$ & $\begin{array}{l}a_{1} \text { and } a_{2} \\
\text { Combined }\end{array}$ & $\beta$ & $\gamma$ \\
\hline $\begin{array}{l}\text { Mean value (\%) } \\
\text { S.D. }(\%)\end{array}$ & $\begin{array}{r}2 \cdot 6 \\
\pm 1 \cdot 37\end{array}$ & $\begin{array}{c}67.9 \\
\pm 4.56\end{array}$ & $\begin{array}{r}70.42 \\
\pm 5.46\end{array}$ & $\begin{aligned} & 3 \cdot 9 \\
\pm & 1 \cdot 37\end{aligned}$ & $\begin{array}{c}4 \cdot 0 \\
+1 \cdot 29\end{array}$ & $\begin{array}{r}7 \cdot 82 \\
\pm 1 \cdot 85\end{array}$ & $\begin{array}{c}17 \cdot 0 \\
\pm 3 \cdot 32\end{array}$ & $\begin{array}{c}4 \cdot 1 \\
\pm 1 \cdot 76\end{array}$ \\
\hline
\end{tabular}

${ }^{1}$ Based on 18 samples from patients without neurological disease.

from 18 patients between the ages of 40 and 70 who had no neurological symptoms or signs, and were lumbar punctured for spinal anaesthesia are shown in Table I for the purpose of comparison. The $\gamma$ globulin determined by the electrophoretic method will hereafter be designated $\gamma(\mathrm{e})$.

Determination of $\gamma$ globulin in the cerebrospinal fluid by immunological assay (hereafter $\gamma(\mathrm{i})$ ) was performed at the Beecham Research Laboratories, Brockham Park, using a rabbit antiserum against human $\gamma$ globulin. The technique (Feinberg, 1958, 1959; Feinberg and Temple, 1961) involves double diffusion in agar gel plates in which an antibody gradient is established by permitting prior diffusion of the antiserum for 24 to 72 hours and subsequent addition of serial dilutions of the antigen to be assayed. The rigidly fixed and accurate pattern of wells is cut in the agar gel with agar gel cutter no. 1812.2 This ensures complete reproducibility of pattern from plate to plate. A known reference antigen is used as a standard and assay is made by comparison of the curved bands of antigen-antibody precipitate formed (Fig. 1).

For the present investigation pooled human serum was used as the reference standard. The total protein of such pooled human serum was estimated by the biuret method of Kingsley (1942). The percentage of $\gamma$ globulin in

${ }^{2}$ Shandon Scientific Co., London; Consolidated Laboratories Inc., Chicago Heights, Illinois.

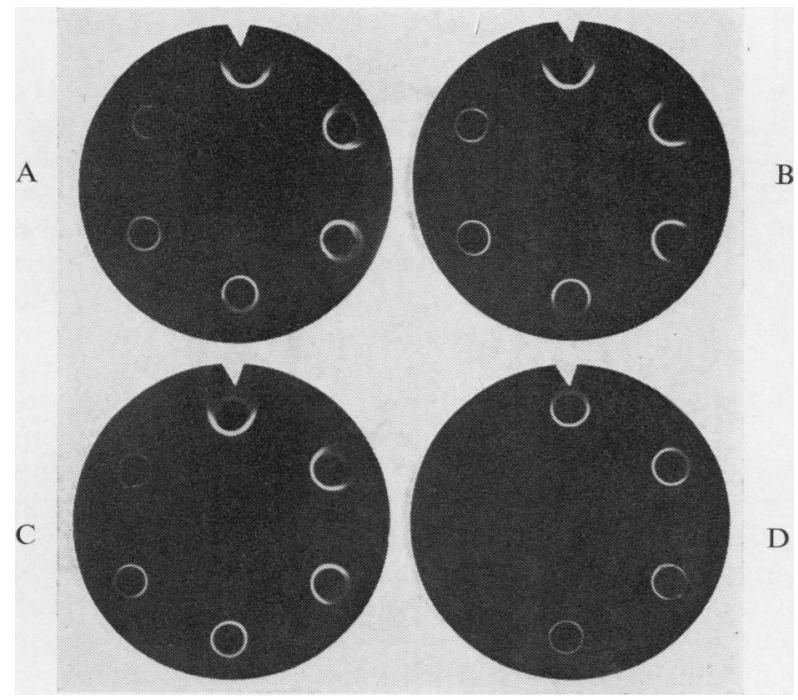

this pooled serum was estimated by electrophoresis on cellulose acetate and staining the strips with Ponceau $\mathbf{S}$, which is an adequate stain for high-protein concentrations of serum. The density of the bands was then measured by the automatic scanner.

\section{RESULTS}

Table II shows the relative and absolute values of $\gamma(\mathrm{e})$ and $\gamma(\mathrm{i})$ found. In the electrophoretic method of assay the percentage value of the $\gamma(e)$ in each specimen of cerebrospinal fluid was obtained as described above and these figures were then converted to absolute values by multiplying by the total protein in the sample and dividing the product by 100.

In the immunological assay, a relative $\gamma(\mathrm{i})$ value was established for each specimen of cerebrospinal fluid by comparing its precipitation pattern against that obtained with a 1:400 dilution of pooled human serum (Fig. 1). The graphic simplicity and objectivity of the method is apparent in the illustration.

The absolute value of the $\gamma(i)$ in each spinal fluid was subsequently estimated as a proportion of the absolute value of $\gamma$ globulin in the pooled serum, as

FIG. 1. Comparison of immunoprecipitation patterns of four specimens produced by immunodiffusion in agar gel plates: A Pooled human serum initial dilution (indicated by notch) 1/400; B cerebrospinal fluid no. 5 (see Table II), initial dilution 1/4.5; C cerebrospinal fluid no. 16, initially undiluted; D cerebrospinal fluid no. 3, initially undiluted. Rabbit antihuman $\gamma$ globulin serum in centre well; $1.5 x$ serial dilutions of the specimens placed clockwise in the circumferential wells. It is immediately apparent that no. 5 contains about five times as much $\gamma(i)$ as no. 16, which is equivalent in $\gamma(i)$ to a 1 in 400 dilution of pooled normal human serum while no. 3 contains less than half as much $\gamma(i)$ as no. 16. This demonstrates the simple, visual objectivity of this immunological assay method. 
TABLE II

COMPARISON OF GAMMA GLOBULIN MEASUREMENT IN CEREBROSPINAL FLUID BY ELECTROPHORETIC AND IMMUNOLOGICAL TECHNIQUES

\begin{tabular}{|c|c|c|c|c|c|c|c|}
\hline \multirow[t]{2}{*}{ No. } & \multirow[t]{2}{*}{ Diagnosis } & \multicolumn{3}{|c|}{ Electrophoretic Assay } & \multicolumn{2}{|c|}{ Immunological Assay } & \multirow{2}{*}{$\begin{array}{l}\text { Ratio of } \\
\text { Immuno- } \\
\text { logical } \gamma \\
\text { Globulin to } \\
\text { Electro- } \\
\text { phoretic } \\
\gamma \text { Globulin } \\
{[\gamma(i) / \gamma(e)]}\end{array}$} \\
\hline & & $\begin{array}{l}\text { Total } \\
\text { Protein } \\
(\mathrm{mg} . \%)\end{array}$ & $\begin{array}{l}\text { Percentage } \\
\gamma \text { Globulin }\end{array}$ & $\begin{array}{l}\gamma \text { Globulin } \\
(m g . \%) \\
{[\gamma(e)]}\end{array}$ & $\begin{array}{l}\text { Proportion of } \\
\gamma \text { Globulin } \\
\text { in Cerebro- } \\
\text { spinal Fluid } \\
\text { Compared } \\
\text { with Pooled } \\
\text { Human Serum }\end{array}$ & $\begin{array}{l}\gamma \text { Globulin } \\
(\mathrm{mg} . \%) \\
{[\gamma(i)]}\end{array}$ & \\
\hline 1 & Cerebral tumour (familial) & 200 & $9 \cdot 8$ & $19 \cdot 6$ & $1 / 545$ & $2 \cdot 1$ & $0 \cdot 107$ \\
\hline 2 & Obstructive hydrocephalus & 275 & $9 \cdot 9$ & $27 \cdot 2$ & $1 / 132$ & $8 \cdot 8$ & 0.323 \\
\hline 3 & Epilepsy & 30 & $5 \cdot 0$ & $1 \cdot 5$ & $1 / 1,000$ & $1 \cdot 16$ & 0.77 \\
\hline 4 & Multiple sclerosis & 35 & $20 \cdot 5$ & $7 \cdot 0$ & $1 / 150$ & $7 \cdot 7$ & $1 \cdot 10$ \\
\hline \multirow[t]{2}{*}{5} & Subarachnoid haemorrhage and & & & & & & \\
\hline & hydrocephalus & 175 & $6 \cdot 5$ & $11 \cdot 4$ & $1 / 88$ & $13 \cdot 2$ & $1 \cdot 15$ \\
\hline 6 & Multiple sclerosis & 60 & $15 \cdot 7$ & 9.6 & $1 / 100$ & $11 \cdot 6$ & $1 \cdot 2$ \\
\hline 7 & Multiple sclerosis & 40 & $15 \cdot 0$ & 6.0 & $1 / 145$ & $8 \cdot 0$ & $1 \cdot 33$ \\
\hline 8 & General paralysis of the insane & 20 & $6 \cdot 9$ & 1.4 & $1 / 600$ & 1.9 & $1 \cdot 37$ \\
\hline 9 & Basilar ischaemia & 80 & $7 \cdot 7$ & $6 \cdot 2$ & $1 / 130$ & 8.9 & 1.43 \\
\hline 10 & Brain-stem tumour & 180 & $3 \cdot 8$ & 10.4 & $1 / 75$ & 15.4 & 1.48 \\
\hline 11 & Tabo-paresis & 100 & $17 \cdot 0$ & $17 \cdot 0$ & $1 / 40$ & $29 \cdot 0$ & $1 \cdot 7$ \\
\hline 12 & Multiple sclerosis & 25 & $11 \cdot 7$ & $2 \cdot 9$ & $1 / 220$ & $5 \cdot 3$ & 1.8 \\
\hline 13 & Multiple sclerosis & 30 & $24 \cdot 1$ & $7 \cdot 2$ & $1 / 86$ & $13 \cdot 5$ & 1.87 \\
\hline 14 & Multiple sclerosis & 70 & $4 \cdot 5$ & $3 \cdot 2$ & $1 / 170$ & 6.8 & $2 \cdot 12$ \\
\hline 15 & Multiple sclerosis & 30 & $17 \cdot 7$ & $5 \cdot 4$ & $1 / 75$ & $15 \cdot 4$ & 2.85 \\
\hline 16 & Basilar ischaemia & 20 & $3 \cdot 7$ & 0.7 & $1 / 400$ & $2 \cdot 9$ & $4 \cdot 14$ \\
\hline 17 & Herpetic encephalitis & 30 & $5 \cdot 9$ & $1 \cdot 8$ & $1 / 140$ & $8 \cdot 3$ & $4 \cdot 61$ \\
\hline
\end{tabular}

established from electrophoretic assay of the latter. Unfortunately, the consumption of the reference serum in the immunological assays made it impossible to do the electrophoretic assay of $\gamma$ globulin on the reference serum actually used but a similar pooled human serum from the same source was used for the electrophoretic assay. Although this might have introduced an approximation into the results, it should, in fact, be constant in relation to the whole series and should not affect the comparison of the results significantly.

A comparison of the $\gamma$ globulin levels obtained by the two techniques discloses some interesting features. While it is clearly premature to draw conclusions from this preliminary investigation, in the results we have obtained $\gamma(\mathrm{i})$ tends to be generally somewhat higher than $\gamma(\mathrm{e})$.

Though the mean ratio of $\gamma(\mathrm{i}) / \gamma(\mathrm{e})$ is about $1 \cdot 7: 1$ in this investigation, there is quite a wide variation in this figure from case to case. The range is from 0.107 to 4.61 , shown at the beginning and end respectively of Table II.

The figure of 0.107 was obtained from a patient with a family history of angiomatosis and meningioma (under the care of Professor R. W. Gilliatt) who presented with severe vomiting of pregnancy and was found to have a high level of protein in the cerebrospinal fluid. Another patient whose cerebrospinal fluid showed a much greater elevation of $\gamma(\mathrm{e})$ than of $\gamma(\mathrm{i})$ had a chronic obstructive hydrocephalus of unknown aetiology. At the lower end of Table II the situation seems materially reversed.

Such gross differences in the ratio of the resultsi obtained by the two methods requires furthero investigation and evaluation, particularly to deter mine whether it has a constant trend for specia? diseases and, therefore, may be of clinical signifi cance. It is of interest to note that most of the spinat fluids of patients with multiple sclerosis tended to fall into two groups on either side of the mean.

\section{DISCUSSION}

A number of factors may affect these results. The first which should be borne in mind is the accuracys of the estimations. The electrophoretic method for absolute values is dependent on measuring the tota? protein in the cerebrospinal fluid and alson the electrophoretic quantitative estimation. Errors may arise in both of these. The total protein esti 0 mation may be affected by the relative proportion ofw different proteins, which alters the density of the precipitate which is being measured. Our results areo based on single estimations. Since small variationsD may occur from time to time, duplicate estimations? would have been more accurate. However, it is considered that variations due to the methods are not likely to be more than the order of 1 part in $10 \mathrm{D}$ of the total figure for $\gamma(e)$. Variations of an ordes sufficiently large to account for the apparento difference observed in Table II have never been seen 
in duplicate studies of the same cerebrospinal fluid by the electrophoretic method employed.

The particular immunological technique used in this investigation has been shown to be of a high order of reproducibility. Though in the present small trial only single estimations were carried out with this technique, it is not anticipated that an error of more than $\pm 10 \%$ will be present. Use of a standard cutting tool has the advantage of ensuring uniformity of results, not only within a particular laboratory but also as between different laboratories. Reading of the precipitation patterns is objective, as each test gel plate can be superimposed over the reference plate and the patterns directly matched, viewing the superimposed pair by transmitted light.

The figure for $\gamma$ globulin obtained in the immunological method of assay in this series is dependent on the estimation of the total $\gamma$ globulin in a pooled human serum. The total $\gamma$ globulin was calculated from the total proteins in the serum after the percentage of $\gamma$ globulin in the serum had been determined electrophoretically. Such error as might have occurred in this measurement should be constant for all the immunological results and the bias should apply to the whole series consistently.

By the electrophoretic method the upper limit for $\gamma$ globulin in 18 normal cerebrospinal fluids was found to be $5 \mathrm{mg}$. per $100 \mathrm{ml}$. (mean plus 2 S.D.). When 2 S.D. is subtracted from the mean, the lower limit for $\gamma$ globulin, as determined electrophoretically in these 18 normal cerebrospinal fluids, is virtually zero. Therefore, it becomes impossible to establish a condition of $\gamma$ globulin deficiency in cerebrospinal fluid but, at the other end of the scale, it may be considered that a concentration of more than $5 \mathrm{mg}$. per $100 \mathrm{ml}$. is pathological. The mean ratio of $\gamma(\mathrm{e})$ to $\gamma(\mathrm{i})$ in the series shown is 1 to 1.7 . If this factor is applied to the normal upper limit of $\gamma(\mathrm{e})$ then the upper limit of $\gamma(\mathrm{i})$ should be of the order of $8.5 \mathrm{mg} . \%$.

These provisional figures can be used as a means of comparing the values of the methods. It can be seen that a rise of total protein, using the figure of $60 \mathrm{mg} . \%$ as the uppermost limit of normal, only detects about $41 \%$ of these fluids as being abnormal and is in fact the least sensitive indicator of abnormality (Table III).

The most sensitive single method is the absolute $\gamma$ globulin estimation by electrophoresis. The two tests combined which pick out the maximum number of abnormal fluids are the total protein plus the relative $\gamma$ globulin by electrophoresis. It is possible that in a larger series the results might well be different.

It is, however, of interest that some fluids which have a normal total protein and a normal $\gamma$ globulin
TABLE III

ANALYSIS OF SELECTED ABNORMAL FINDINGS IN 17 PATHOLOGICAL SPINAL FLUIDS

\begin{tabular}{lc} 
& $N o$. \\
\hline $\begin{array}{l}\text { Raised total protein } \\
\text { Raised } \gamma \text { globulin by immunological assay }\end{array}$ & $7(41 \%)$ \\
$\begin{array}{l}\text { Raised total protein and/or raised } \gamma \text { globulin by } \\
\text { immunological assay }\end{array}$ & $\mathbf{8}(47 \%)$ \\
$\begin{array}{l}\text { Relative rise in } \gamma \text { globulin by electrophoresis } \\
\text { Raised absolute } \gamma \text { globulin by electrophoresis } \\
\text { Raised protein and/or raised absolute } \gamma \text { globulin by } \\
\quad \text { electrophoresis }\end{array}$ & $10(59 \%)$ \\
$\begin{array}{l}\text { Raised protein and/or raised relative } \gamma \text { globulin by } \\
\text { electrophoresis }\end{array}$ & $11(65 \%)$ \\
$\begin{array}{l}\text { Raised protein and/or raised } \gamma \text { globulin by electrophoresis } \\
\text { and/or by immunological assay }\end{array}$ & $13(71 \%)$ \\
& $13(76 \%)$
\end{tabular}

either by electrophoresis or by immune assay, appear at the extremes of the Table II and might thus be regarded as pathological on the basis of their $\gamma(\mathrm{i})$ and $\gamma(\mathrm{e})$ ratios. Fluids nos. 1 and 16 (Table II) had approximately similar amounts of $\gamma(\mathrm{i})$, yet there was a 28-fold difference in $\gamma(\mathrm{e})$ between them. By contrast, fluids nos. 3 and 17 were determined to have similar levels of $\gamma(\mathrm{e})$, but a six-fold difference in $\gamma(\mathrm{i})$. It is too early, yet, to assess the significance of such differences.

In the current investigation immunological assay was carried out with a rabbit antiserum which seems to be monospecific for human serum $\gamma$ globulin. No antibody to other serum proteins has been detected in it either by immunodiffusion or immunoelectrophoresis. However, a particular advantage of this immunological assay technique is that, should the antiserum contain traces of antibodies to other proteins, these will produce separate weak precipitation bands which should not interfere with the assay of the $\gamma$ globulin (Feinberg and Temple, 1959).

Some of the differences between the electrophoretic and immunological results are undoubtedly due to the fact that substances which travel as $\gamma$ globulin in an electrophoretic system, e.g., the 'minor C.S.F. $\gamma$ globulin' of MacPherson and Cosgrove (1961), may not be immunologically identical with serum $\gamma$ globulin. Under these circimstances the figures by the electrophoretic method for $\gamma$ globulin would be higher than those obtained for the immunological test.

On the other hand, protein which is immunologically similar to $\gamma$ globulin may travel electrophoretically with other components. Under these conditions the immunological figures will be higher than the electrophoretic figures as regards the $\gamma$ globulin. It is interesting to speculate whether certain clinical conditions introduce into the cerebrospinal fluid proteins which are immunologically identical with $\gamma$ globulin, though they do not move electrophoretically with this protein; and, conversely 
whether other clinical conditions raise the level of the 'minor $\gamma$ globulin', or introduce into the cerebrospinal fluid proteins which travel with $\gamma$ globulin electrophoretically but have different antigenic identity.

The subject appears to merit further investigation, particularly in regard to the clinical significance of the discrepancies between $\gamma(\mathrm{e})$ and $\gamma(\mathrm{i})$, when these occur.

We are pleased to acknowledge the help received from Dr. Michael Kremer and encouragement from Professor Sir Charles Dodds, P.R.C.P., at whose suggestion this work was undertaken. Facilities were kindly provided by Professor A. Kekwick and the Clinical Research Committee of the Middlesex Hospital at the Institute of Clinical Research, Middlesex Hospital Medical School. Samples of normal cerebrospinal fluid were provided by Dr. L. H. Morris and members of the staff of the Gordon Hospital, Vauxhall Bridge Road, London, 0 S.W.1. The Medical Research Council have provided a grant to one of us (J.C.) for technical assistance 을 and apparatus for this work, and we are also glad to $\Rightarrow$ acknowledge that some of the apparatus used was pro- $\stackrel{9}{?}$ vided by the Multiple Sclerosis Society.

\section{REFERENCES}

Colover, J. (1961a). Biochem. J., 78, 5P.

(1961b). J. clin. Path., 14, 559.

Dencker, S. J., and Swahn, B. (1962). Nature (Lond.), 194, 288.

Feinberg, J. G. (1958). Proc. 4th int. Congr. Biological Standards, $\vec{\theta}$ Brussels, p. 194.

(1959). Immunology, 2, 346.

$\ldots$, and Temple, A. (1959). Proc. int. Symp. Immunology, Opatija, p. 401.

_- (1961). Protides of Biological Fluids, p. 312. Elsevier, Amsterdam.

Frick, E., and Scheid-Seydel, L. (1960). Klin. Wschr., 38, 1240.

King, E. J., and Hazelwood, G. A. D. (1936). Lancet, 2, 1153.

Kingsley, J. (1942). J. lab. clin. Med., 27, 840.

MacPherson, C. F. C., and Cosgrove, J. B. R. (1961). Canad. J. Biochem., 39, 1567.

\section{The May 1963 Issue}

\section{THE MAY 1963 ISSUE CONTAINS THE FOLLOWING PAPERS}

De Quervain's subacute granulomatous thyroiditis: histological identification and incidence G. MEACHIM and M. H. YOUNG

Muco-epidermoid tumours of the anal canal B. C. MORSON and H. VOLKSTÄDT

The histogenesis of carcinoid tumours of the rectum N. M. GIBBS

Wegener's granulomatosis: report of a patient surviving four and a half years D. W. EVANS and J. B. W. HALLEY Metaplasia of renal glomerular capsular epithelium DONALD J. MACPHERSON

Further observations on platelet aggregation induced by adenosine diphosphate thrombin and tri-ethyl tin J. R. O'BRIEN

Marrow biopsy in the diagnosis of pyrexia of undetermined origin N. D. GOWER

A drug-specific leuco-agglutinin in a fatal case of agranulocytosis due to chlorpromazine G. C. HOFFMAN, J. S. HEWLETT, and F. L. GARZÓN

Urea distribution in renal failure D. J. BLACKMORE, W. J. ELDER, and C. H. BOWDEN

A method for $\mathrm{I}^{131}$ conversion ratio utilizing the plasma inorganic $1^{131}$ fraction H. OYAMADA and E. IRENE PENTZ

A routine method for the determination of phosphoglucose isomerase activity in body fluid J. E. HORROCKS, J. WARD, and J. KING

Sensitive methods for the titrimetric microdetermination of biological calcium and magnesium R. N. BEALE and J. о. воSTrom
Observations on the cytological diagnosis of an infectious. erythema CRISAN MUSETEANU and D. VISINESCU

Sterilization of air filters for high pre-vacuum autoclaves R. J. FALLON

The effect of carbohydrates on the production of staphy-م lococcal pigment A. E. BROWN and HILDA R. HARRIS Techniques for the rapid and sensitive detection of penicillinase R. J. HOLT and G. T. STEWART

Infections due to methicillin-resistant strains of Staphy lococcus pyogenes J. W. HARDING

A case of vaccinia necrosum (or progressive vaccinia) with severe hypogammaglobulinaemia, treated with $n_{i}$ methyl isatin beta-thiosemicarbazone (33T57) T. H] FLEWETT and F. L. KER

Comparison of colicine production and diffusion on different solid media J. MCGEACHIE and w. MCCORMick

Technical methods

Detection of autoantibodies to cytoplasmic and nuclea antigens in freeze-dried thyroid R. C. NAIRN, T. GHOSE I. B. PORTEUS, and J. A. URQUhART

Detection of auto-immune antibody and tissue antigen by the 'microspot' technique J. G. FEINBERG

The estimation of $\beta$ amino-isobutyric acid in human urin D. BAWDEN

A gel diffusion precipitin method for the estimatiol? of C-reactive protein R. A. CROCKSON

A method for the comparison of the antiplasmin activity of two groups of blood sera MARGARET HOWELL

Book reviews

Copies are still available and may be obtained from the PUBLISHING MANAGER, BRITISH MEDICAL ASSOCIATION, TAVISTOCK SQUARF, W.C.I., price 18s. 6D. 